\title{
The clot thickens for long-lasting drugs that stop hemophilia short
}

Cazandra MacDonald's 16-year-old son is more concerned with musical theater and video games than he is with sticking to an injection schedule. Her 6-year-old is afraid of needles. Yet both boys have severe hemophilia $A$, and nearly every other day they require concentrates of clotting factor VIII to be slowly dripped into their veins to prevent the types of bleeding episodes that can severely damage their joints and organs.

"It's not like someone with diabetes, where you can give a shot anywhere," says MacDonald, who lives in Albuquerque, New Mexico. "You have to find a vein, and sometimes too much scar tissue builds up in your old faithful places and you have to go to the hospital or clinic to get help." Once she locates the vein, an infusion of clotting factor takes about an hour. "It would be absolutely wonderful if we didn't have to infuse so often."

New drugs nearing the market could help, with several companies now seeking regulatory approval for longer-lasting treatments for hemophilia A, a recessive, sex-linked disease that affects around 1 in 5,000 males born in the US, and the related factor IX deficiency known as hemophilia B, which is about five times less common. "It's really exciting," says Steven Pipe, a pediatric hematology specialist at the University of Michigan Medical Center in Ann Arbor. "We've been using the same products for decades. Now we see this breadth of clinical trial activity and novel strategies."

Biogen Idec is far and away the leader in this space. On 4 January, the Massachusettsbased company announced that it had filed for US approval of its long-lasting hemophilia B treatment, BIIB029. Biogen also plans to submit its hemophilia A candidate, BIIB031, in the first half of 2013. Both treatments combine the clotting factor of interest-VIII in the case of hemophilia A, IX for hemophilia B-with a fragment of a human immunoglobulin protein that protects the conjugate product from degradation, thereby enabling the drugs to remain in circulation longer.

Biogen and its Stockholm-based partner Swedish Orphan Biovitrum released positive top-line results from open-label phase 3 trials for both candidates last year. More than $90 \%$ of bleeding episodes could be stopped with a single injection of either product, the companies reported, and prophylactic treatment could be given as infrequently as every two weeks for BIIB029 and every 3.5 days for BIIB031. (Current treatments are generally dosed two to three times per week.) The pharmacokinetic data were equally impressive: the approximate half-life of BIIB029 was 82 hours compared to 34 hours for BeneFIX, a recombinant factor IX product from New York's Pfizer that is currently the gold-standard therapy for hemophilia B, while BIIB031 had a half-life of 19 hours, compared to 12 hours for Advate from Illinois-based Baxter.

What's more, the studies showed no signs of people developing antibodies against the drugs-something that has sunk many experimental clotting factor agents before. "The safety profile, assuming it continues to look good, really will usher in a new era of treatment for people with hemophilia," says Glenn Pierce, chief medical officer for Biogen's hemophilia program.

\section{Got you PEGged}

If approved, the products are expected to cut into the $\$ 5$ billion global market for factor VIII therapies and the $\$ 1$ billion market for factor IX drugs. Yet the Biogen agents might soon have competition in the long-acting arena. On 7 January, Baxter launched a 146-person trial assessing a version of clotting factor

The VIII/IX factor: Long-lasting hemophilia therapies in late-stage development.

\begin{tabular}{|c|c|c|c|c|}
\hline & Company & Product & Product Type & Stage \\
\hline \multirow[t]{4}{*}{ Hemophilia A } & Biogen & BIIB031 & $\begin{array}{l}\text { Recombinant factor VIII Fc fusion } \\
\text { protein }\end{array}$ & $\begin{array}{l}\text { Awaits } \\
\text { filing }\end{array}$ \\
\hline & Novo Nordisk & N8-GP & $\begin{array}{l}\text { GlycoPEGylated recombinant fac- } \\
\text { tor VIII }\end{array}$ & Phase 3 \\
\hline & Bayer HealthCare & BAY 94-9027 & PEGylated recombinant factor VIII & Phase 2/3 \\
\hline & Baxter & BAX855 & PEGylated recombinant factor VIII & Phase $2 / 3$ \\
\hline \multirow[t]{3}{*}{ Hemophilia B } & Biogen & BIIB029 & $\begin{array}{l}\text { Recombinant factor IX } \\
\text { Fc fusion protein }\end{array}$ & Filed \\
\hline & Novo Nordisk & N9-GP & $\begin{array}{l}\text { GlycoPEGylated recombinant fac- } \\
\text { tor IX }\end{array}$ & Phase 3 \\
\hline & CSL Behring & CSL654 & $\begin{array}{l}\text { Recombinant factor IX albumin } \\
\text { fusion protein }\end{array}$ & Phase 3 \\
\hline
\end{tabular}

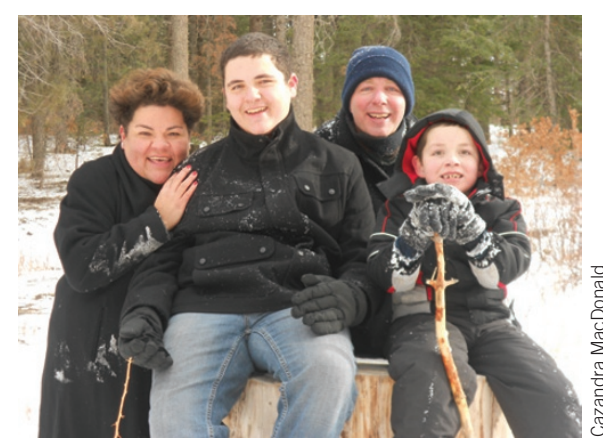

Living with hemophilia: The MacDonald family.

VIII attached to a polyethylene glycol (PEG) residue. This process, known as PEGylation, increases the size of the factor protein molecule, which prevents the kidneys from clearing it and allows the drug to last longer in the blood. In phase 1 trials, the half-life of the experimental Baxter drug, dubbed BAX855, was about 1.5 times higher than the company's current bestseller Advate, putting its stability on par with that of Biogen's BIIB029.

Similarly, Denmark's Novo Nordisk and New Jersey's Bayer HealthCare are in the final stages of clinical tests of PEGylated clotting factor therapies, while Pennsylvania’s CSL Behring has a fusion protein that links the blood serum protein albumin to factor IX for added stability. Early studies indicate that some PEGylated and albumin-bound products may outlast Biogen's immunoglobulin fragment-tagged therapies, but phase 3 data aren't yet available.

All these drug options, if approved, could be a boon for patients like the MacDonald boys. "Having multiple options is important," says Margaret Ragni, director of the Hemophilia Center of Western Pennsylvania in Pittsburgh who has tested Biogen's new agents. "With hemophilia, one size doesn't always fit all."

"Keep your eyeball on gene therapy, too," notes Pipe. In 2011, clinicians at University College London, using a gene therapy product developed by researchers at St. Jude Children's Research Hospital in Memphis, Tennessee, made a big splash when they successfully treated six patients with hemophilia B by injecting them with the correct form of a defective gene (N. Engl. J. Med. 365, 2357$2365,2011)$. Pipe estimates it will take another five to ten years to bring gene therapy for hemophilia B to market, with hemophilia A farther behind because of the difficultly of expressing factor VIII. Still, he says, "everyone sees gene therapy as the way forward for an ultimate cure for hemophilia."

Alisa Opar 